\title{
Královské lesy v Maiestas Carolina: Monumentalita krajiny a právní pluralismus $v$ procesu utváření suverenity českého království
}

\author{
The Royal Forests in Maiestas Carolina: Monumentality \\ of Landscape and Legal Pluralism in the Making of Sovereignty \\ of the Kingdom of Bohemia
}

Tomáš Ledvinka

\begin{abstract}
De juribus regiis silvarum (On the Law of the Royal Forests) is a segment of an unrealised constitutional project for the Kingdom of Bohemia from the mid-fourteenth century (Maiestas Carolina) which is usually interpreted as a law to protect the Royal Forests from arsonists and other criminals to maintain them as a source of the king's revenue. This paper reinterprets the regulation with the emphasis on the interconnection between the Royal Forests and the constitutional mythos of the inalienability of the Kingdom. It suggests that the designation of the Forests to protect the wild (trees, beasts and outlaws) was based not merely on reverence for the king but also on the seclusion of the landscapes from intensive human use by means of a robust material, military-bureaucratic infrastructure (castles, roads...) which was equally meant to establish the Forests as an autonomous and constitutive pillar of the Kingdom's sovereignty. It shows how the monumental landscape of the Royal Forests acquired a specific legitimacy function in terms of heterogeneous space and legal pluralism in the Kingdom, which is contrasted to the national territoriality and House metaphorics of modern State sovereignty. The paper further analyses the remarkable societal arrangement of the Maiestas Carolina Forest Court, which represents a unique configuration for the resolution of conflicts between various legal units and micro-sovereignties situated within the landscape of the Kingdom.
\end{abstract}

KEYWORDS forest, kingdom, landscape, legal pluralism, sacred, sovereignty, state formation, wilderness

Sociální studia / Social Studies 2/2020. S. 71-90. ISSN 1214-813X.

1 Rád bych poděkoval za cenné připomínky dvou anonymním recenzentkám/recenzentům, kteří výrazně prohloubili mé porozumění předmětného tématu. Velký dík patří rovněž Jiřímu Woitschovi za konzultaci ohledně pramenů $\mathrm{k}$ historii lesa. Zpracování tohoto článku bylo podpořeno grantem v rámci Specifického výzkumu č. 2106/02330 Fakulty informatiky a managementu Univerzity Hradec Králové. Za pomoc s technickou stránkou rukopisu děkuji studentům Veronice Vlasákové a Danielu Nývltovi. 


\section{Úvod}

Královské lesy jsou v legislativním textu Maiestas Carolina z poloviny čtrnáctého století chápány jako jedna z opor nezcizitelnosti suverenity zemí Koruny české. Taková nepřirozená fakta se zpravidla nacházejí za obvyklým horizontem zkoumání formativních dějin státu, suverenity či práva. Jestliže však např́klad Elias zkoumá sociogenezi státu skrze metamorfózy vidličky či kapesníku (Elias 2006, 2007), jak by monumentální královské lesy mohly nehrát svou roli v dlouhodobé transformaci království na stát, když byly navíc ve středověkém světě pokládány za jeden z atributů královského majestátu. Obvyklé zahrnutí královských lesů do obecnější kategorie lesů a jejich redukce na pouhé vnější prostředí sociokulturních dějů se zdá být výsledkem zlomového chápání historického vývoje státu, které nacházíme například u Maxe Webera. Stát dle něj vznikl „vyvlastněním soukromých nositelů vrchnostenské pravomoci“ (Weber 2009, s. 243-293), aniž by reflektoval, jaké důsledky může takto jednostranné pojetí mít pro současné chápání historického vývoje suverenity. Obdobné schéma nacházíme např́klad i u Bourdieua, který chápe stát jako výsledek monopolizace „symbolického násilí“ (Bourdieu 1998, s. 74). Úskalí tohoto sociologického přístupu ke státu spočívá v tom, že umožňuje indiferenci k tomu, co bylo před státem. Jmenovitě Bourdieu dohlédne nejdále $\mathrm{k}$ absolutistickému státu dynastického typu, jenž těsně předcházel moderní nacionalizaci sociálního prostoru, když se na podkladě své etnografie berberského př́bytku pokouší vzkřísit nepřiměřenou ideologii státu jako „domu“ (Bourdieu 2014, s. 139-140). Představa o svrchovanosti paní berberského domu aplikovaná na stát implikuje úplné podřízení jeho vnitřního teritoria absolutní, nepodmíněné a statické státní suverenitě. Taková představa je však jen ideologií určitých epoch, která pramálo vypovídá o skutečných konfiguracích suverenity v jednotlivých historických obdobích.

Význam královských hvozdů pro ustavování svrchovanosti království v českých zemích poloviny čtrnáctého století ${ }^{2}$ je proto vhodnější zkoumat spíše z perspektiv historiografického nazírání proměn prostoru (Klimek 2014, s. 37-102) či antropologického chápání krajiny (Pauknerová a Gibas 2015). Základním poznatkem vyplývajícím z porovnání moderní a středověké ústavy je totiž to, že zatímco v současnosti se suverenita vztahuje k abstraktnímu, zevšeobecnělému teritoriu bez vnitřní právní segmentace, Maiestas Carolina ji v předgeografickém období ${ }^{3}$ doslova vetknula do konkrétních míst, krajin a oblastí, z nichž učinila opory nezcizitelnosti království. Mezi nimi je královským lesům přisouzeno významné místo. Nelze ostatně přehlédnout ani to, že ve srovnání s několika zmínkami o přírodním bohatství v současné Ústavě České republiky věnuje Maiestas Carolina královským lesům mimořádně rozsáhlou ústavněprávní úpravu. Absenci královských hvozdů v moderním (nejen sociologickém a právnickém) pojetí státní suverenity tak lze považovat za skutečnost neméně závažnou, než je jejich přítomnost ve zmíněném středověkém ústavním díle. Na svazku středověkých právních pravidel, který v Maiestas Carolina počíná ustanovením De juribus regiis silvarum (O právu královských lesů) ${ }^{4} \mathrm{se}-\mathrm{s}$ ohledem na tuto nesouměřitelnost - pokusím

K problematice přesné datace viz Šusta (1948, s. 213-214).

První mapa Čech je podle všeho mapa Mikuláše Klaudyána z roku 1518 (Novotná 2018).

V tomto článku vycházím z překladu Maiestas Carolina do českého jazyka (Jireček ze Samokova 1870). 
ukázat, že přiléhavějším východiskem pro zkoumání sociogeneze suverenity jou rozmanitost, rozmístění a průniky právních systémů $\mathrm{v}$ prostoru či krajině stř̌edověkého království spíše než jakási nadčasová „esenciální struktura metafyzické tradice“ (Agamben 2011, s. 15) či „absolutní definice suverenity“ (Derrida 2009: 57). Právě situovanost práva královských lesů v předstátní krajině a zároveň v mozaice právních systémů uvnitř království nám může napovědět, že suverenita je spiše procesem, který se odehrává na konkrétních místech, jakož i v prostoru, který se sám dosud neprestal vyvíjet. ${ }^{5}$

Představa suverenity, která spolu s právem a státem shlíží z vyvýšeného piedestalu abstraktní teorie na empirickou realitu, staví ve svých důsledcích procesuální stránku suverenity stranou. Je však třeba si uvědomit, že tento nadempirický pohled je jen svorníkem velkého teoretického rozdělení světa na př́rodu a kulturu, o něž se legitimita moderní státnosti opírá. Pokud však suverenitu umístíme do krajiny jako jejího referenčního rámce, uvidíme, že suverenita je namáhavě prosazovaná a podmiňovaná mnoha faktory. Historická skutečnost práva královských lesů a lesních soudů navíc zvýrazňuje nerovnoměrnou distribuci svrchovanosti v právně fragmentovaném prostoru středověkého českého království. S tím se ovšem pojí i její závislost na transcendentních, mimolidských a mimospolečenských pramenech legitimity, které lze spatřovat, mimo jiné, v monumentalitě a (již ve čtrnáctém století patrné) archaičnosti některých oblastí krajiny. Snad kvůli tomuto nerovnoměrnému rozprostření suverenity $\mathrm{v}$ krajině je $\mathrm{v}$ českých právních dějinách - tolik zneklidňovaných geopolitickou nejistotou a snažících se primárně prrispívat $\mathrm{k}$ historickému odůvodnění samostatné české státnosti - reflexe těchto skutečností vzácná, byt’ jinde je problematika královských lesů pokládána za významnou součást „ústavních dějin“ (Jørgensen 2010), a její smysl je zpravidla interpretován environmentálně jako „ochrana lesa před úplnou destrukci““ (Young 1978). V českém prostředí si proto existence zvláštního, pro královské lesy příznačného práva povšimli spíše autoři na poli kulturních dějin lesa než právního dějepisectví. Např́ílad Woitsch postř̌ehl (maje na mysli cechy lesních řemeslníků), že v lese se bylo možné setkávat nejen s „folklórem, zvyky, ale i právním systémem“ (Woitsch 2007, s. 179, pozn. 29) Podobně Klimek upozorňuje na to, že pojem „správcové lesa, forestarii““, který byl v českém království zaveden právě ve čtrnáctém století, ${ }^{7}$ se „,vztahoval ke specifickému druhu správy, vyňaté z běžných zákoníků církevního i zvykového práva“ (Klimek 2014, s. 165, pozn. 66). $\mathrm{V}$ př́ípadě královských hvozdů lze nadto dovodit př́mou jurisdikci krále, která je v rámci Maiestas Carolina (čl. 89) označována jako zvláštní panování, dominium speciale. Zvláštnímu panování krále podléhala kromě lesů rovněž různá královská města, hrady a kláštery. $\mathrm{Z}$ toho důvodu tato kategorie sama zahrnuje různé právní ŕády a představa specifického lesního „královstvi““ jako místa, kde platí zvláštní zákony, není tak zcela nepodstatná nebo „pohádková“. Radikální odlišnost právního řádu středověkého královského hvozdu koresponduje s ,anomálií“ na první pohled viditelnou přinejmenším v prostoru starého sídelního

$5 \quad \mathrm{~K}$ antropologickému tématu krajiny jako procesu viz, např́klad, Pauknerová (2019).

$6 \quad$ K problematice dějin lesa viz též naprríklad Woitsch (2010). Z novějších studií viz například Blažková (2019).

7 Správcové lesa se na západě Evropy objevují v právních textech od doby Karolínské říše (Bechmann 1990, s. 235). 
území vnitřních Čech, kde jsou jinak již prakticky všechny ostatní části krajiny zemědělsky či technicky využívány (Klimek 2014, s. 46).

Tento článek je rozčleněn následovně: nejprve se zabývá dopadem rozdělení královských lesů mezi moderní vědní obory na uznání svébytného významu jejich práva. Poté reflektuje, kde je toto právo situováno, kam je umístuje Maiestas Carolina v rámci právního uspořádání království jakož i v rámci jeho krajiny a prostoru. Dále poukazuje na kontrast mezi ústředním principem Maiestas Carolina, nezcizitelnosti suverenity, který má své opory v monumentálních oblastech krajiny, a technizací současné krajiny, jež naopak podléhá principu totální disponovatelnosti. Poté se obrací k tématu, jak je svazek královských lesů se suverenitou krále autonomizován a jak monumentální segmenty krajiny získávají specifickou legitimizační funkci. Následuje rozbor pozoruhodného societárního uspořádání lesního soudu v Maiestas Carolina, který ukazuje, že jednotlivé právní systémy a mikrosuverenity uvnitř království korespondují s určitými místy a oblastmi v krajině. Následně se zaměřuje na segmenty teorie království, které jsou v literatuře spojeny s královskými lesy, jež v segmentárním právním prostředí pomáhají semknout království dohromady. V závěru nechávám vyjít najevo kontrast mezi středověkou představou suverenity vetknuté do krajiny a moderním pojetím státu jako domu.

\section{Královské lesy mezi kulturou a prírodou, ekonomikou a posvátnem}

Různé podoby vztahu lesa, suverenity a práva lze stopovat od pohanských hájů jako sídel předkřest’anských právních autorit přes královský hvozd jako atribut královského majestátu až například po hospodářský les jako zdroj obchodního artiklu, dříví. Dnes dominující formy vztahu práva a lesa jsou často neoprávněně promítány na staré právní světy jako celek, což vede k nerozpoznání jejich podstatných strukturálních odlišností. Pod prizmatem kapitalistické modernity se na ochranu královských lesů hledí zpravidla jako na ochranu zdroje královských př́ijmů. Je to však totéž, jako bychom si dnes spletli vlastnictví hospodářského lesa se správou národního parku. S ohledem na environmentální krizi je ochrana královských lesů obdobně ahistoricky interpretována jako protoprávo ochrany životního prostředí. Avšak $\mathrm{v}$ takovém př́ípadě jsme opět zapomněli na vzájemnou souvztažnost středověkých náboženských mytologií a lesa. „To druhé“, co nám v těchto analogiích uniká, totiž zůstává za dělící př́čkou moderního teoretického rozčlenění světa na společnost a př́rodu (Latour 1993, s. 13-48). Vytěsnění stř̌edověkého práva královských lesů z badatelského zájmu těch, kteří se zaměřují na sociogenezi suverenity či státnosti, př́padně jeho redukci na pouhou historickou kuriozitu, odpovídá na druhé straně obdobná tendence výzkumníků, kteří se zaměřují na environmentální dějiny. Např́klad dle Ložka je biosférická rezervace Křivoklátsko „rozsáhlou souvisle zalesněnou oblastí [...], v jejímž středu se nachází starý královský hrad [zvýrazněno autorem]“. V rámci environmentálně dějepisného popisu Křivoklátska coby „území, kde se vegetace a drobná fauna vyvíjela po celý postglaciál bez většího narušení lidskými zásahy“ představuje právě „starý královský hrad“ jen ozvláštňující zmínku. Důraz je naopak kladen na „nerušený vývoj lesních ekosystémů [...] v mladším holocénu“, a na to, že v Křivoklátsku lze spatřovat, ,jedinou oblast, kde se dodnes na četných místech zachoval př́rodě blízký stav př́slušných ekosystémů“ a existují tam „ekosystémy, které jinde zanikly“ či „,původní prírodní 
stav“ (Ložek 2001). Na druhé straně Nachtmannová a Razím - v rámci kulturně historického zaměření - pojímají Křivoklátsko jako ,les zvláštního poslání a značně svébytného vývoje [zvýrazněno autorem]“, tedy spíše než jako dějiště politicky významných rituálů, např́ílad lovu. Lov přitom primárně pokládají za ,jeden z nejmarkantnějších prostředků demonstrace politické moci a osobní síly vládce“ a zároveň „,součást kultury [...] šiřííí se [ze západní Evropy - pozn. autora] i do dalších evropských zemí" (2010, s. 12). Archeologické závěry o významu lesa tito autoři přitom opírají například o architektonické provedení hradu Křivoklátu anebo o strategické umístění sídel, stezek a jiné infrastruktury v hvozdu: „[c]elkový výraz, k němuž Křivoklát dospěl v období Přemysla Otakara II., neomylně prokazuje význam, který král přisuzoval nejen hradu, ale také loveckému hvozdu ve své domácí i zahraniční politice $\mathrm{v}$ době, kdy rozšiřoval své panství $\mathrm{v}$ alpských zemích, a nebránil se pomyšlení na říšskou korunu [zvýrazněno autorem]“ (Nachtmanová a Razím 2010, s. 20). V královském hvozdu je tak kultura a historie semknuta a niterně provázána s ekosystémy a biosférou, a přesto výrazně teoreticky oddělena, takže z úplného obrazu se může problematika práva královských lesů, která se nachází právě na místě interdisciplinárního předělu, snadno vytratit.

Máme proto velké štěstí, že se právní úprava De juribus regiis silvarum (O právu královských lesů) dochovala jako součást Maiestas Carolina v textové podobě a že jsme nyní, vědomi si metadiskurzivních omezení vyplývajících z moderního rozčlenění jednotlivých vědních disciplín, schopni reflektovat více jeho významových vrstev naráz. Přesto naráží interpretace tohoto pramene na určité limity. Při absenci dalších písemných pramenů z daného období se totiž může tento pramen jevit jako osamělý archeologický monument, který nemá na teritoriu českých zemí obdobu, ${ }^{9}$ a je tak obtížně př́stupný interpretativnímu porozumění. Protějšky českých královských hvozdů lze však dohledat v západoevropských křest’anských královstvích té doby a jejich soudobé výzkumy je rozhodně neredukují na nástroje kulturní reprezentace či př́rodní prostředí. Porozumění právu středověkých královských lesů v Maiestas Carolina se proto musí nutně opírat o západoevropskou odbornou literaturu, a to zejména $\mathrm{z}$ oblasti kulturních dějin lesa a právního dějepisectví. Nejsměrodatnější vodítka však paradoxně nabízí spíše literatura staršího data, napríklad postřehy Micheleta, Grimma i jiných (Gierke 1895, s. 399; Grimm 1828, s. 346; Grimm 1840-1863; Hübner 1918, s. 271-275; Matteson 2015, s. 158; Thimme 1909). Právě tito autoři totiž výrazně přispěli k přerodu obskurních, obtížně srozumitelných právních starožitností, které s procesem mizení světů, $v$ nichž původně operovaly, ztratily své původní významy. ${ }^{10}$ Jejich pracemi se z nich staly objekty hodné vědeckého studia.

8 Jedná se zejména o články 49-57 (Jireček ze Samokova 1870, s. 145-150). Latinské pojmenování úvodního „lesního“ ustanovení De juribus regiis silvarum překládá např́klad Jireček jako „O právě králových lesuov“ (Jireček ze Samokova 1870, s. 146).

9 Nepočítáme-li v to fragment o lese v tzv. Knize Rožmberské z let 1358-1361 (Teige 1904) a Chebský lesní řád z roku 1371 (Kubů 1992).

10 K problematice středověkých právních starožitností a ztráty jejich původních významů viz například Ledvinka (2020a). 
Pro správné porozumění situovanosti práva královských lesů v předstátní krajině i v korespondující mozaice právních systémů uvnitř království je však zapotřebí vycházet i z výzkumů právního pluralismu v lesích prrípadně i mimo evropskou půdu (Graziani a Burnham 2005; Purabi, Arts a Dijk 2012; Vandergeest 1996).

V českém prostředí byly pro pochopení významu královských lesů užívány spíše kategorie ekonomické teorie, jako je např́klad monopol. Pro interpretaci komplexních (tedy nejen ekonomických) jevů může však tato inklinace vést k tomu, že specifické, tedy ty nejdůležitější charakteristiky předmětu studia budou zredukovány pouze na jeden aspekt, pokládaný z nějakého důvodu za jediný reálný. Př́íkladem může být právě redukce královských práv na jura regalia, mezi něž patří i „hvozdy královské a královská výsost lesní“ (Kadlec 1897a). Regály jsou obvykle označovány za královské monopoly - „výsostní práva panovníkova, jež byla pramenem jeho př́jmu“ (Kadlec 1897b). Podobné důsledky však může mít i např́klad zaměření historickoprávní školy na duchovní kulturu, které implikuje, že vývoj práva se odehrává spíše v kabinetech právních učenců (Kantorowicz 1957) než v plenéru. Skutečnost, že úprava královských hvozdů v Maiestas Carolina obsahuje o hospodářské problematice jen jednu explicitní zmínku (ustanovení o plavení dřeva) ${ }^{11}$, by však vážně míněný výzkum měla vést spíše k umenšení důležitosti jejich hospodářských významů. Podobně skutečnost, že spory o hranice královských hvozdů jsou rozhodovány v plenéru, by nás měla naopak varovat i před druhou zmíněnou představou. Snahu o porozumění královským lesům výhradně v ekonomických či právnických kategoriích lze zkrátka pokládat za „předčasné uzavření“ jejich popisu (Latour 2005, s. 260).

Fundamentálně jiný směr interpretace naznačuje naopak rozsáhlé právnické dílo Johna Manwooda Treatise of the Forest Laws, které je sice z doby pozdější než Maiestas Carolina (1717), podle všeho však reflektuje i starší právní dějiny lesů anglických. V čem tento směr interpretace spočívá? Jak na to upozorňuje Harrison (1992, s. 73), „přesný latinský ekvivalent" anglického termínu forest je sylva sacrosancta nebo saltus sacrosanctus, tedy v češtině „přesvatý“ nebo „svatosvatý“ hvozd (Manwood 1717, s. 151-152), tj. mohli bychom říci les vyjmutý z instrumentálního či profánního užívání. K tomu viz též Below a Breit (1998). V kontextu christianizace Evropy a českých zemí ve čtrnáctém století zvláště ${ }^{12}$ se přitom pravděpodobně nejedná o přetrvávající prvek pohanského světa, nýbrž jde spíše o významovou sedimentaci křest’anskou, která př̌krývá dřívější významy krajiny interpretací královských lesů jakožto biblické divočiny ${ }^{13}$ (pouště, hory či řeky). V tomto duchu jsou královské lesy chápány jako duchovní útočiště, místo osudových zkoušek a obrody. Naopak nepřátelské pojetí lesa, které do lidové kultury středověku zavedli někteří autoři jako součást lidových christianizačních strategií, v Maiestas Carolina nenajdeme. Právní pojetí královských lesů tak v době Lucemburků navazuje spíše na tradici vysoké kultury a západní identity

11 Toto ustanovení předepisuje určité „formy“ a „znamení“, bez nichž je třeba zabránit dalšímu pohybu dřeva po vodě. Dřevo patrně může pocházet i z královských hvozdů. Kontrola je však vždy uskutečňována královskými „hrady, které nad vodou sedi““ (Jireček ze Samokova 1870: 150). Ustanovení o plavbě dřeva je rovněž jediné, které se prostorově vzdaluje od královských hvozdů samých.

12 Srov. zejména Nodl a Šmahel (2020).

13 Srov. pojem desertum u Klimka $(2014,50)$. 
přemyslovských knížat a králů, jež nemusí nutně korespondovat se skutečnými náboženskými poměry a lidovou kulturou v zemi. Podstatné je v tomto ohledu jistě i západní teologické a právnické zakotvení autora a redaktorů zákoníku (Šusta 1948, s. 219-220). Zda je toto právní pojetí skutečnou křest’anskou sedimentací, která překryla starší, pohanskou úctu ke konkrétním lesům, však dosud nebylo předmětem detailního výzkumu.

Zjevným účelem právní úpravy královských lesů v Maiestas Carolina přitom je, jak na to upozornil Klimek, právě jejich zachování a trvání do budoucnosti (2014, s. 59). Semknutí suverenity středověkého království s archaickými lesy, jejichž trvání v čase není ani zdaleka zaručeno, se tak může jevit jako neprožretelné. Ostatně opakovaná hrozba zániku lesů byla $\mathrm{v}$ kontextu západoevropského civilizačního vývoje té doby již zřejmým faktem (Young 1978, s. 95). Nesamozřejmost existence královských lesů se však zdá být překlenuta právě jejich ústavněprávním zakotvením jakožto nezcizitelných opor neméně nejisté suverenity království. Ohledně určení, jak účinné toto právní pojetí ve skutečnosti bylo, je přitom nutné výzkum práva středověkých královských lesů rozšǐriit mimo symbolickou sféru právní normativity, přinejmenším pokud si ji spojujeme s moderními podmínkami, jak před tím varuje např́klad Chiffoleau (1999). Pravidelnosti lidského chování k lesu, které lze za určitých okolností chápat jako odraz práva, totiž nacházejí svůj výraz zejména v jejich trvání, zániku či konkrétní podobě. Jejich environmentální dějiny jsou tak důležitým indikátorem skutečného, aplikovaného práva. Zachování kontinuity anebo naopak zánik jednotlivých královských lesů představují tak pro právní dějepisectví zásadní environmentální fakta.

\section{Kde je situováno právo královských lesư?}

Právo královských lesů se chronologicky nachází před anebo mimo moc velkých moderních teoretických rozdělení světa, např́ílad na kulturu a př́rodu. Máme-li proniknout do jejich skutečného hájemství, musíme najít způsob, jak procházet těmito teoretickými a metadiskurzivními zdmi. Právo královských lesů představuje totiž svět, který se rozkládá pod rozparcelovaným teoretickým povrchem. ${ }^{14} \mathrm{Z}$ tohoto hlediska je toto právo především hybridem: spojuje v sobě prvky kulturní (království, suverenita, nezcizitelnost aj.) a prírodní (les) do jediného, vzájemně podmíněného kulturně přírodního komplexu. Jinými slovy, metadisciplinární rozčlenění moderních věd „rozkládá“ každý královský hvozd - a zejména jeho právní rozměr - do předem uchystaných teoretických vymezení disciplinárních předmětů. Jeho jednotlivé prvky spadají bud' mezi atributy království do sféry historie a kultury, nebo do kategorie př́rody či krajiny (Blok a Torben 2011, s. 66). Takto pojatá dvě odborná teritoria královského hvozdu si mezi sebou velmi zhruba rozdělili na jedné straně archeologové a historici a na druhé straně př́rodovědci a environmentální historici.

Na jakou disciplinární parcelu však spadne samo právo, které je z našeho hlediska určujícím pojmem? Ve svých kulturních dějinách lesa to velmi zřetelně demonstroval Harrison. Podle něj představují královské lesy morální či etické „stíny“ práva, způsobu vlády, mentálních konvencí a forem jednání v lidské kultuře (Harrison 1992, s. 61-106). Dobrodiní práva

14 K problematice vztahu modernity a popisu viz např́klad Latour (2016a). 
přitom náleží jen využívané krajině a lidské společnosti. Harrisonova analýza příběhů o psancích, kteří se v těchto lesích ukrývají, zároveň pozoruhodně poukazuje na význam lesního azylu, který umožňuje obrodit právní kulturu lidí prostřednictvím vy̌šší spravedlnosti divočiny (viz níže v tomto článku). Hranice mezi lesem a lidmi je přitom asymetrická, o čemž svědčí inverzní varianty psaneckých př́iběhů o „vlcích v komnatách institucí (Harrison 1992: 78). Právě tento motiv však ve skutečnosti poukazuje na jinou konfiguraci vztahu práva a lesa.

V kontrastu s tímto pojetím se pokusím ukázat, že hranice mezi přírodní spravedlností a lidským právem není pro právo královských lesů jakkoliv konstitutivní. Naopak, královské lesy - spíše než aby byly práva prosté - představují jednu právní oblast vedle mnoha jiných v mozaice středověkého právního světa. Středověké právo je totiž situováno v prostoru a krajině, jsou pro ně důležité hranice i vzdálenosti vnitřního i vnějšího rozčlenění království, aniž by tím jakkoliv ztrácelo svůj mobilní či personální aspekt. ${ }^{15}$ Jak jsem již zmínil, královské lesy v Maiestas Carolina jsou koncipovány jako atribut království a opora nezcizitelnosti jeho suverenity. Suverenita krále sice vyztužuje robustnost a monumentalitu královských lesů za pomoci infrastruktury stezek, hradů a sídel v hvozdu, stejně jako monumentalita lesů je užita k legitimizaci království tím, že umožňuje jeho vetknutí do krajiny, ale královský dvưr a zejména král sám cestují v krajině a pobývají na různých místech (Dvořáčková-Malá a Zelenka 2011, s. 178-193). Tuto krajinu však v žádném př́ípadě není možné ztotožnit s abstraktním geografickým prostorem, vymezeným zeměpisnou šířkou a výškou, který je předpokladem moderní právní teritoriality.

Do svérázného vztahu mezi suverenitou a předstátní krajinou se proto pokusíme vstoupit právě přes interpretaci lesních ustanovení Maiestas Carolina. Abychom unikli pastem etnocentrismu a prezentismu, musíme vycházet spíše z komparativního, etnologického pojmu práva (Pospíśil 1997, s. 14-65; Ledvinka 2015; Ledvinka 2020b, s. 13-15) než z doktríny svazující právo výlučně se státem. Na rozdíl od projekcí současné představy státního práva a státnosti do minulosti je totiž nespornou výhodou etnologického pojetí, že umožňuje odlišit právo v terénu od jiných kulturních jevů (zvyků, obyčejů apod.) na základě otevřeného souboru kritérií, aniž by bylo podstatné, zda právo operuje na úrovni státu či na jiných societárních rovinách. Pospíšilovo pojetí práva v sociální antropologii doplňuje i komparativně analytický pojem suverenity, resp. „mikrosuverenity“, jejímž referenčním rámcem je taktéž mozaika societárních uskupení, nikoliv státnost (Humphrey 2007). ${ }^{16}$ Nejenže východiska těchto pojmů přesněji souhlasí s právní situací zachycenou v Maiestas Carolina, ale s jejich pomocí ji můžeme rovněž přesněji pochopit. ${ }^{17}$ Přesto je však nepochybné, že právo královských lesů se nachází právě na nejvyšší rovině societárního uspořádání a zařazení svazku

15 K problematice práva v prostoru viz např́íklad Ledvinka (2014).

16 K této antropologické perspektivě se někdy, a poslední dobou stále častěji, blíží právní dějepisectví operující s antropologickým pojmem právního pluralismu (Seinecke 2017) či multinormativity (Duve 2017).

17 I tradiční právní dějepisectví pozvolna reflektuje skutečnost, že evropská středověká království je třeba reflektovat $\mathrm{z}$ hlediska jejich právní segmentace. V tomto ohledu lze odkázat např́klad na autory jako je Kern (Liebrecht 2016), Ullman (1978, s. 89-108) či Stollberg-Rillinger (2013). 
právních ustanovení De juribus regiis silvarum do Maiestas Carolina svědčí nejen o právní, ale též širší kulturní, např́iklad i teologické a kosmologické důležitosti, která se královským lesům přikládala. Je proto nutné se zabývat i otázkou, jaká je povaha Maiestas Carolina jakožto pramene práva.

Když Pavel Ješín tento text v roce 1617 vydal, užil pro jeho označení tento titul: Maiestas Carolina sive Constitutiones Caroli IV. Rom. Imperatoris, quibus ille regnum Bohemiae formandum ornandumque censuit (Palacký 1844, s. 66). I když jej někteří autoři, např́klad nestor lesního dějepisectví Nožička (1957, s. 35-38), označují za zákoník či kodex, Maiestas Carolina rozhodně nebyla zamýšlena jako obecný zákoník, nýbrž jako konstituce - kodex ústavního práva. Ostatně se také v souladu se svým názvem docela soustavně zaměřuje na vymezení suverenity zemí Koruny české a jejích opor. Jejich situování do krajiny může být přitom chápáno v souvislosti se snahou osamostatnit království - přinejmenším do jisté míry - od živého krále a jeho nedostatků. Určitá zdrženlivost užívat $\mathrm{v}$ této souvislosti termín ústava vyplývá dle mého názoru ze skutečnosti, že text obsahuje úpravu řady oblastí včetně právě ochrany lesa, které jsou dnes obvykle řazeny hlavně do podústavních zákoníků či zákonů (např́íklad do zákona o ochraně př́rody a krajiny). Zjevně zde však narážíme na odlišnost $\mathrm{v}$ tom, co je pokládáno za ústavně důležité. Latinské pojmenování textu jako Constitutiones je proto třeba pokládat za dokonale přiléhavé.

Maiestas Carolina je inovací v sociálně antropologickém smyslu (Pospíšil 2004, s. 68-75), výrazem právní reformy vstupující do kontextu jiné právní kultury. Zákony jsou v této kultuře vázány na partikulární komunity či místa, nikoli všeobecně na teritorium či společnost. Nabývají zpravidla symbolických forem, které se vymykají textualitě. Ačkoliv králova maiestas, jejímž atributem jsou i královské lesy, zahrnuje i suverénovo postavení nad právem (článek 43), obecná artikulace vztahu mezi suverenitou krále a právem v království je složitější a paradoxnější. Král je ze své vlastní vůle na jedné straně vázán zákony, avšak na straně druhé je právě jeho maiestas vyňata z jurisdikce soudů: soudní proces musí být strukturován tak, aby ani formulací žaloby maiestas neutrpěla (ibid.). Sémantice slova maiestas v Maiestas Carolina věnovala dosavadní literatura pramálo pozornosti. Je patrné, že tento termín v sobě nese mnoho dílčích významů, jako jsou např́iklad čest, důstojnost, vznešenost, velikost, výsost, prestiž, jurisdikce, ale právě i suverenita. Antropologická literatura o cti a právu v segmentárních společnostech se proto jeví jako přiléhavá zásobárna analytických prostředků pro jeho přesné rozklíčování.

O převaze segmentárního uspořádání jednotlivých právních systémů uvnitř království nad textovými formami práva ostatně dosti svědčí i to, že tento návrh ústavy pro království nikdy nebyl přijat jako platné právo, nebot' z moci prozřetelnosti údajně „shořel“ před přísahami a publikací (Šusta 1948, s. 402). Právní řád království (at' už jej označíme jako zemské právo či jinak) musel zkrátka respektovat skutečnost, že není jediným právním řádem v království. Tato historická situace je patrná v jednotlivých ustanoveních Maiestas Carolina včetně práva královských lesů. Lesní ustanovení zákoníku se této situaci přizpůsobují a usilují spíše o drobné posuny v jejím rámci než o její překonání. Na Maiestas Carolina jako sepsání ústavního práva se proto nevztahuje legalistický předpoklad moderních zákoníků, že komplexně podchycují všechny sociální vztahy ve vytčené oblasti. Jedná se naopak spíše jen 
o „doplněk místních právních systémů“ (Pospíšil 1997: 23), včetně místního práva zemského a královského, do nichž nám nedává zcela nahlédnout. ${ }^{18}$

Je pozoruhodné, že z hlediska systematického uspořádání Maiestas Carolina jsou ustanovení o právu královských lesů umístěna hned za obranu zemských hranic, vnějších mezí království. Královský lesy totiž představují jakousi vnitřní mez království. Jak naznačují Nachtmanová a Razím (2010, s. 21) na př́íkladu Kř́ivoklátska, význam tohoto královského hvozdu představuje krajinný rámec pro manifestaci královského majestátu při přijímání zahraničních delegací, reprezentativnost královského hvozdu ve středu království je kombinovaná s jeho odlehlostí od osídleného území. Přitom se nachází v relativní blízkosti sídelního města. Poukazuje to na mezinárodní rozměr tohoto vnitrozemského území s výraznou prostorovou mobilitou osob (ibid.) a je tím zdůrazněna i skutečnost, že vnitřní právní rozčlenění království zahrnuje vedle právních oblastí, které lze označit za lokální, i takové, které jsou otočeny ven, do evropské soustavy křest’anských domén, Res publica Christiana. V této souvislosti je třeba zmínit známý fakt, že za nezcizitelné opory království jsou pokládány nejen lesy ale i města a hrady nacházející se mimo tradiční vnější meze království (Šusta 1948, s. 400).

Sám pojem královských hvozdů je dosti neurčitý. Př́ikře to kontrastuje s podrobnými výčty nezcizitelných královských hradů a měst. Známé textace Maiestas Carolina neobsahují, až na výjimky, označení konkrétní polohy ani rozsah královských lesů. V jiných ustanoveních je zmiňován pomezný hvozd v Krušných horách za Ústím nad Labem a Mostem (čl. 72) a hvozd u Albrechtic př́slušný k Hradci Králové. Je nicméně jisté, že pojem nedopadá na jedinou lesní oblast, nýbrž zahrnuje vnitrozemské i pomezní hvozdy, např́íklad královský hvozd Křivoklátska (Nachtmanová a Razím 2010) nebo hvozd v okolí Kašperku a při boubínské zemské bráně (Holý 2007). Neurčitost pojmu lze patrně přičíst na vrub dynamickému procesu změn soustavy královských lesů, které nebyly v době vzniku zákoníku dosud skončeny. Tyto změny souvisely jednak se zakládáním a výstavbou nových hradů v pomezních oblastech, jednak se zanikáním nebo omezováním některých původních královských hvozdů ve starém sídelním území vnitřních Čech, což se týká např́íklad přenesení některých funkcí kamýckého „lovčovstvi““ ve středním Povltaví (Boháč 1978, s. 72-73) na Karlštejn.

Lesní ustanovení Maiestas Carolina se týkají čtyř tematických okruhů, které jsou dohromady provázány leitmotivem nezcizitelnosti královských hvozdů. První okruh se týká revize vlastnických vztahů $\mathrm{k}$ půdě, která byla $\mathrm{v}$ minulosti vymýcením odloupnuta od královských lesů a stala se z ní osídlená zemědělská krajina (Jireček ze Samokova 1870, s. 148). Nad touto půdou zákoník znovu zavádí královskou lesní jurisdikci. Opětovné přičlenění těchto oblastí bylo přitom zdůvodněno jejich „věčnou“ přináležitostí ke královskému hvozdu (Jireček ze Samokova 1870). Tento nadnesený poukaz na kontinuální trvání královských lesů v čase však není nutně pouze tradičním zdůvodněním majetkového nároku krále. Druhý

18 Klimek ohledně královských lesů uvádí, že „,v nich platí specifické zákony“. V této souvislosti pak zmiňuje, že Maiestas Carolina ,částečně vychází z existujícího zvykového práva“ (2014: 59). Tuto otázku je obecně žádoucí objasnit, avšak užití nejasných pojmů právního dějepisectví (zejména zvykové právo a obyčejové právo) takové objasnění spíše ztěžuje. Jiné, analytické pojetí zvykového práva viz Pospíšil (1997, s. 66-75). 
tematický okruh se totiž týká ochrany královských lesů před zemědělskými a technickými záměry obyvatel království, které probíhají nebo mohou probíhat v budoucnosti. Tato ustanovení dopadají nejen na situace, kdy do královského hvozdu vstupují lidé z vnějšku a svými činnostmi ohrozí, poškodí nebo zničí les, nýbrž patrně i na situace, kdy takové záměry pojmou obyvatelé hvozdu. Třetím tematickým okruhem je ochrana hranic královských hvozdů ve vztahu k sousedním šlechtickým panstvím, jejímž pozadím je právě vnitřní právní rozčlenění království.

\section{Od králova lesa k lesu království}

Jak obrana proti ohrožení lesa ve formě zemědělské činnosti (druhý okruh), tak ve formě narušení jeho pozemkových mezí od sousedních pánů nachází svi̊j protějšek v sebeomezení králů $\mathrm{v}$ možnosti zcizovat královské hvozdy nebo jejich části, které vyplývá z celkové koncepce trvalosti a nezcizitelnosti opor království a kontinuity („věčnosti““) maiestas. Problematika nezcizitelnosti suverenity království konkretizovaná v monumentálních prvcích středověké krajiny je v tomto smyslu souměřitelná s tím, co Weiner na př́kladu aboridžinského času snění chápe jako „nezcizitelnost krajiny, [která] skýtá materiální formu mýtům“, jež jsou „napojeny na skutečné geografické lokace jako jeskyně, kameny a potoky“ (1992: 162, pozn. 54). V tomto výrazném omezení disponovatelnosti s královskými lesy tkví také hlavní důvod, proč na ně nelze hledět jednoduše jako na majetek krále či zdroj jeho příjmů. Oprávnění s věcí disponovat se pokládá za esenciální segment moderního vlastnického práva. V „nezcizitelnosti držav“ (Weiner 1992, s. 60) se tak nabízí jeden ze styčných bodů př́ípadné komparace středověké mytické krajiny s technickou krajinou sevřenou v „totální disponovatelnosti“ a určenou pro průmyslové provozy a obchodní oběh (Novák 2007,s. 101-103), jež ovšem vyžaduje právní zvěcnění či „reifikaci“ živého lesa do podoby netečného jsoucna (Pottage a Mundy 2004, s. 6).

Právě $\mathrm{k}$ ochraně nezcizitelnosti suverenity, která je umístěna do krajiny, spíše než k ochraně pozemkového vlastnictví krále, směřuje i stanovení sankcí pro určité typy narušování královských hvozdů. Pro svou brutální povahu jsou zpravidla pokládány za jakousi formu středověkého trestního práva. ${ }^{19}$ Dosud se však žádný výzkumník nepozastavil nad tím, že takové hodnocení jejich povahy neodpovídá humanizující tendenci celého kodexu jinak zapovídajícího krutost či brutalitu $\mathrm{v}$ právních formách, ani nad skutečností, že do popředí u těchto sankcí výrazně vystupuje princip vzájemnosti, když např́íklad pokácení stromů v královském hvozdu či useknutí jejich větví je opláceno useknutím údů. Za vyvolání požáru pak ustanovení De impositione ignis ad silvas ukládá sankci upálení (Jireček ze Samokova 1870, s. 149). Středověká a koneckonců i biblická symbolika spojovala požáry se suverenitou. Sankci upálení lze proto interpretovat jako odpověd’ na přivlastnění si požáru jako symbolického výrazu suveréna. Nejspíše proto textace zmíněného ustanovení ani nerozlišuje žd'áření jakožto činnost zemědělskou a technickou a žhářství jakožto zlovolné jednání bez hospodářského kontextu. Můžeme tak hovořit o zřejmé symetrii mezi lesem a člověkem,

19 S ohledem na povahu „lesních“ sankcí je namístě otázka, zda „strach z lesa“ není v lidovém vnímání podpořen jejich tvrdostí a krutostí. Srov. např́iklad Woitsch (2006) či Klimek (2014). 
která je pro nás dnes velmi neobvyklá. Spíše než distinkci mezi věcmi a osobami tak na pozadí těchto ustanovení nalezneme představu o rovnocenných protějšcích (lesa a lidí). Avšak s tou výhradou, že se zde nesetkáváme s „personifikací“ lesa (Pottage a Mundy 2004, s. 6) jako v pohanském světě anebo ve smyslu moderních práv divočiny. Spíše se jedná o rozšíření cti krále, maiestas, i na královské lesy. Narušení královského hvozdu však nemá být stíháno osobně králem ve formě odvetného boje (feudu). Maiestas Carolina naopak vyžaduje soustavné sankcionování konkrétní materializace středověké suverenity království. Jde tedy o formu spojení královského lesa s osobou suveréna, která zároveň směřje $\mathrm{k}$ jeho odpojení jako autonomního atributu královské cti od konkrétního krále. Králův les se tak v důsledku tohoto procesu stále více proměňuje $\mathrm{v}$ les království.

Objektivní ústavněprávní ochranu královských lesů (i před králem samým) je tak možno klást do souvislosti s procesy odpoutávání jednotlivých atributů království od živých králů. Autonomizace královských hvozdů podobně jako koruny jakožto druhého těla krále (tedy určité samostatné korporace) se s ohledem na právo královských lesů neodehrávala pouze v učeneckých disputacích královských právníkủ, jak to naznačuje Kantorowicz (1957), nýbrž v prostoru celého království, do něhož byly např́klad rozesety symbolické reprezentace suverenity ve formě mincí a pečetí s vyobrazením znakủ královského majestátu. Do procesu utváření autonomní suverenity království, jehož pregnantním výrazem je právě zákoník Maiestas Carolina, byly však rovněž vtaženy monumentální krajinné prvky. Jde v něm ostatně právě o to, že potenciálně absentující král symbolicky zajišt'uje svou trvalou př́tomnost v krajině království, aniž by musel spoléhat pouze na svou osobní prítomnost, svou mobilitu či mobilitu svého dvora (Dvořáčková-Malá a Zelenka 2011, s. 178-193).

\section{Soud královského hvozdu}

Čtvrtý, avšak v jistém smyslu ústřední, tematický okruh lesních ustanovení se týká organizace právní autority, kterou pro zjednodušení označuji jako lesní soud. Jeho jurisdikce dopadá na spory o hranice královských lesů se sousedními šlechtickými panstvími, avšak nelze jej pokládat za prostý mezní soud ${ }^{20}$. Jeho účelem je totiž zjevně ochrana nezcizitelnosti královských hvozdů jakožto opory suverenity království. Hranice, o něž by se vedl spor, nejsou vždy nutně rozmezím mezi zemědělsky užívanou krajinou a oblastí archaického lesa, jako je tomu v ostatních tematických okruzích. Do popředí zde vystupuje spíše societární rozčlenění království na jednotlivé právní oblasti, což je výrazně patrné zejména $v$ tom, že koncept „práva“, který nalezneme v ustanovení De juribus regiis silvarum, neodkazuje na systém pravidel, nýbrž na problematiku vnitřního uspořádání lesního soudu, která toto societární rozčlenění království na právní oblasti odráží. Právo královských lesů tak odkazuje především na soud se zcela specifickým posláním ve vztahu k suverenitě, na jeho organizaci a složení.

Vzájemný vztah suverenity království a práva $\mathrm{v}$ království je $\mathrm{v}$ př́ípadě tohoto druhu soudu symbolicky zvýrazněno tím, že král, př́ípadně i prostřednictvím svého lovčího, je sice v postavení předsedajícího soudu, ale tento rys není výrazem jeho hierarchické nadřazenosti.

20 Přehled literatury o mezním soudu viz např́iklad Klabouch a Procházka (1956, s. 158). 
Přítomnost krále je symbolem práva a suverenity spíše než faktorem strukturujícím povahu soudu. Jeho rozhodnutí není totiž ve skutečnosti legitimizováno a prosazováno seshora $\mathrm{z}$ hlediska jakési ústřední suverénní moci, nýbrž se naopak zdá opírat o přesvědčivost argumentace sporných stran, která je podepřena situační mocí i právní autoritou, jíž každá ze sporných stran chová $\mathrm{v}$ rámci svého jednotlivého panství. Na zasedání soudu se totiž účastní rovným počtem zástupci královského lesa i druhé sporné strany: devět hajných nebo služebníků z královského hvozdu, devět vladyků či panošů sousedního svobodného panství a jeden až dva rytî́i. Všechny je přitom třeba pokládat za členy tribunálu. Jinými slovy, každý z nich plní funkci soudce (byt’ zřejmě může plnit i jiné funkce). Soud královského lesa je tedy ad hoc vytvořenou sociální asociací určenou $\mathrm{k}$ řešení konkrétního sporu, jejíž legitimita se sytí zespodu. Je složený $\mathrm{z}$ jednotlivců, kteří mají zřejmý vztah $\mathrm{k}$ projednávané věci, a vyznačuje se tak přes-jurisdikční vzájemností mezi královským hvozdem a svobodným panstvím, mezi nimiž prochází sporná hranice.

Právě ve vzájemnosti, jež se projevuje v samém složení soudu, nachází svůj výraz sebeomezení královské suverenity spočívající v respektu k suverenitě druhé sporné strany. Suverenitu krále je tedy nutné chápat jako societárně podmíněnou, závislou na relacích s mikrosuverény uvnitř království a strategicky se omezující na vytčené prvky spíše než na komplexní realitu sociálních vztahů. Výrazná absence předem daných a jasně vyjádřených právních pravidel pro řešení tohoto druhu mezních sporư ${ }^{21}$ je tak vysvětlitelná právě tím, že při lesním soudu dochází k setkání dvou právních systémů a jsou přítomny dvě „mikrosuverenity“ (Humphrey 2007, s. 435) uvnitř soudu, spíše než tacitním předpokladem jakéhosi obecně sdíleného mezního práva. Setkání dvou mikrosuverenit totiž vyžaduje spíše pragmatické pojetí práva opírající se zejména o moc přesvědčivosti uvnitř soudu a nutnosti obhájit a prosadit rozhodnutí soudu zároveň ve dvou oblastech s potenciálně odlišným pojetím jejich vnitřních právních pravidel.

V tomto uspořádání je tak zašifrována prostá logika: král jako předseda soudu lesa (a tím i lesní soud sám) je respektován právě proto, že symbolicky vystupuje pouze jako princeps inter pares a respektuje jiné pány a panství. Za mocenských podmínek v českých zemích poloviny čtrnáctého století, kdy existuje značná vyrovnanost mezi šlechtickými magnáty a králem, je princip královské samovlády v Maiestas Carolina zjevně překryt principem právě zmíněným. Jaká konkrétní konstelace vzájemných mocenských vztahů se projeví v konkrétním sporu, zůstává v tomto návrhu základního zákona země otevřené. Do budoucna tak $\mathrm{v}$ tomto ústavněprávním rámci není a priori vyloučena ani možnost koncentrace suverenity $\mathrm{v}$ rukou krále, a tím i cesta $\mathrm{k}$ jinému uspořádání uvnitř království. Na př́ípadnou absolutní suverenitu krále je tak v daném historickém období třeba nahlížet jako na právem přípustné situační faktum spíše než na principiální imperativ.

21 Výrazná absence pravidel pro rozhodování lesního soudu může svědčit o přeshraniční povaze lesního soudu, situovaného na hranici dvou právních systémů. 


\section{Lesy v králově slově, lov a lesní azyl jako prvky teorie království}

Maiestas Carolina je vyjádřením určité teorie království, o to cennější, že je přizpůsobena konkrétní segmentární právní krajině daného období. Královské lesy jsou v ní zařazeny mezi nezcizitelné opory suverenity království a v textu kodexu jde především o jejich zachování a ohraničení. S jakou formou práva se však setkáváme uvnitř královských lesů jakožto oblasti zvláštního panování krále? Pro alespoň dílčí rekonstrukci teorie vnitřního práva královských lesů, je-li ji vůbec možno docílit, musíme hledat její zřetelnější prvky zejména $\mathrm{v}$ západoevropské literatuře. V této části článku se proto snažím načrtnout, jak některé z těchto zřetelnějších prvků, (královo slovo, lov a azyl) teoreticky fungují právě ve vztahu k vnitřnímu právnímu rozčlenění království.

Ohledně formy práva uplatňované v královských lesích např́iklad Thimme hovoří o králově právu - Königsrecht (1909), jehož fundamentálním výrazem je verbum regis. A „být ve verbum regis [pro určité lesy - pozn. autora] znamenalo být v králově slově a požívat jeho ochrany“ (Shoemaker 2018: 254). Jestliže určité lesy jsou v králově slově, jejich právní význam je nejen „vštěpován pro pamět“", ale existuje také vojenská a byrokratická infrastruktura zajištující a prosazující ,کrečenou vưli panovníka“ (Bellomo 1995: 44). Určitým paradoxem královského hvozdu, jelikož jej lze chápat jako protipól osídleného světa, je tak nejen prítomnost krále $\mathrm{s}$ jeho dvorem a př́padnými zahraničními delegacemi $\mathrm{v}$ jeho rámci, ale právě i prítomnost této infrastruktury umístěné do krajiny královského lesa, at již po jeho obvodu a nad řekami, či též v jeho středu. Nezbytnost této infrastruktury plyne z toho, že ani král ani dvůr nepobývají v hvozdu trvale. V království se vládne takříkajíc z koňského sedla, král i dvůr se hojně přemist'ují a cestují (Dvořáčková-Malá a Zelenka 2011, s. 178-193), pohybují se v krajině. Avšak má-li být královský les chráněn královým slovem, musí být trvale prostoupen mocí suveréna. $Z$ toho důvodu se zřizují jeho hrady, jeho pověřenci, jeho právo. ${ }^{22}$ Účinnost situování některých segmentů krajiny - včetně královských lesů - do králova slova máme dnes možnost posuzovat spíše archeologicky, např́klad z hlediska existence materiální infrastruktury nezbytné k prosazení práva uvnitř a po obvodu královských lesů či environmentálně, pod zorným úhlem jejich trvání, proměny botanického složení apod. Je přitom třeba odmítnout romantické interpretace o vážnosti, jaké poživalo královo právo samo o sobě. Respekt ke slovu krále se nevznášel ve vakuu, nýbrž se opíral právě o efektivní infrastrukturu.

Vyjmutí královských hvozdů ze všednosti osídlovacích procesů, obchodování či možnosti rozvinutí feudu nebo jiných odvetných mechanismů středověké kultury tak není pouze záležitostí duchovní kultury učené právní knihovědy, nýbrž se odehrává v plenéru. V oblasti dnešní biosférické rezervace Křivoklátsko např́klad figuroval „systém kamenných hradů

22 Pokud jsme v tomto ohledu na správné stopě, lze zvažovat, zda by Maiestas Carolina nebylo možné pokládat za sepsání dosavadního, př́ípadně nového králova slova. Tento kodex by pak byl výrazem posunu od králova slova ke slovu královskému či ke slovu království. Proti této tezi o procesu autonomizace králova slova ve formě ústavněprávního textu však svědčí skutečnost, že v některých bodech nezavazuje jen a výhradně krále. I tak však lze uvažovat přinejmenším o tom, že verbum regis, které bylo v podmínkách svého vlastního světa relativně účinnou formou práva, představovalo přinejmenším určité jádro kodexu. 
v hvozdu“, jejich posádek a úřad lovčího (Nachtmanová a Razím 2010, s. 14, 20). Jelikož se některé královské lesy (např́ílad právě Křivoklátsko) zachovaly dodnes a jiné nikoliv, můžeme rovněž dovodit, že trvalost této infrastruktury nebyla stejnoměrně rozprostřená, př́ipadně se lišila $v$ různých historických obdobích. Právě tato infrastruktura spojuje slovo krále s krajinou a zajištuje zachování hvozdu jako autonomního atributu království bez závislosti na konkrétním živém králi. V tomto ohledu tak královský hvozd představuje jednu z krajinných materializací „mýtu“ království (Roux 2008, s. 151-152). Monumentální královské hvozdy jsou proto rovněž ztělesněním určité představy světa a poslání politického celku. Avšak právě $\mathrm{k}$ plnému semknutí krále a království, které se odehrává v krajině, a jiných osob, artefaktů, rituálů, míst a oblastí je potřebná rovněž svazující teorie, která všechny tyto prvky umístí do vzájemných souvislostí, v daném př́ípadě jde o teorii království.

V královském hvozdu se podle některých autorů teorie království soustřed’uje zejména kolem lovu. Např́iklad podle Harrisona tento rituál umožňuje králi vydobýt si suverénní postavení rovněž uprostřed divočiny, ve světě šelem (Harrison 1992, s. 74). Smysl králova pobytu $\mathrm{v}$ divočině tak není primárně zábava ani povyražení, nýbrž opětné potvrzení jeho postavení, jeho replikace ve světě zviřrat, a tímto způsobem dochází i k obnovení či „obrodě“ spravedlnosti lidského práva (Roux 2008, s. 151-152). Teorie království je tak v jistém smyslu teorií korespondence: král v lidském království opakuje při lovu stejnou manifestaci svého statusu i ve světě divočiny. Zopakování téhož vzorce suverénní autority ve dvou odlišných světech je přitom jedním ze základních legitimizačních gest středověkého království. Odtud vyplývá ostatně rovněž představa, že „neřády v lidském světě resonují i v prírodě, nebot' je ohrožen samotný řád věcí“ (Taylor 2002: 94). Patrně z toho důvodu jsou v nitru království vyčleněny oblasti, které skýtají „útočiště“ či „,azyl“ (Harrison 1992, s. 61) pro divoká zviŕata i psance, a to před pravidly různých právních řádů osídleného světa.

Azyl královského hvozdu má totiž za cíl stabilizovat středověkou společnost, jak naznačuje Harrison (1992, s. 83), a to z toho důvodu, že se v něm uplatňují jiná pravidla. Psanci, který je známou figurou suverenity (Agamben 2011, s. 106-113; Derrida 2009, s. 74-79), může les poskytnout dočasnou ochranu. Psanec se v něm vydává na milost a nemilost králi, avšak ta mu může zachránit holý život, ne však navrátit ztracenou čest (Šusta 1948, s. 401). Azyl jako určitý výsledek přechodu mezi jednotlivými právními systémy uvnitř království tak nelze nazírat jako nedokonalost práva, nýbrž právě jako charakteristiku, jejímž cílem je obnova spravedlnosti patrně skrze srovnání s psaneckým prožitkem nespravedlnosti lidského práva a pravidly divočiny prožitými králem.

Při středověkém rozčlenění krajiny do působností různě situovaných právních systémů se tak nikdy neocitáme mimo právo, $v$ jakési čisté, práva zbavené morálce, kultuře či prŕrodě. Jestliže psanec hodlá odejít z jednoho právního světa, může to učinit jen tak, že vstoupí do světa jiného práva (srov. napríklad Harrison 1992, s. 75-81). Stále proto zůstáváme v př́tomnosti autorit, at' už otců, vůdců smeček či králů, anebo je nutné se jimi stát. Pro oblast bez práva a bez autorit v teorii království není skulina. Královský hvozd tedy není „,antitezi““ či „inverzi“ práva, nýbrž jeho variantou, stejně jako není „inverzí krajiny“, nýbrž jejím druhem (Harrison 1992, s. 83). Stejný význam jako královským lesům se např́klad v biblické tradici přikládá horám či pouštím (Feldt 2012b) anebo v tradicích jiných vřesovištím, řekám, potokům, ledovcům, jeskyním nebo jiným podobám divočiny (Feldt 2012a; Le Goff 1992; 
Oelschlaeger 1991; Williams 2016): je to místo, z něhož se obrozují zákony lidského světa skrze opětné vyjednávání úmluvy se světem mimolidské divokosti. Právo v teorii království tak má určitou zvláštní kvalitu: možnost svého opětného vytvoření v azylu jiného právního systému uvnitř království. Tomuto prvku Maiestas Carolina, totiž královským lesům, tak není nic více vzdáleno než představa jednoho právního systému vztahujícího se na „celé stvoření“ (Harrison 1992, s. 64). Svět království je zkrátka ontologicky utkán z mozaiky společenství, která jsou nadána vlastním právním sebeurčením. Mezi těmito společenstvími lze cestovat a jejich vzájemné hranice jsou nestálé a nejisté podobným způsobem jako vnější hranice středověkých království jako celků.

\section{Suverenity mezi domem a krajinou}

Archeologové si někdy představují lidstvo jako „obět' sil mimo jeho porozumění a kontrolu“ (Trigger 1984: 367). Moderní uvažování o suverenitě a právu obvykle vymíst'uje takovou představu do minulosti nebo do jiných kultur. Ani vzrůstající hrozivost environmentální krize dosud zpravidla nevedla $\mathrm{k}$ reflexi iluzornosti suverenity států ve vztahu např́klad ke klimatickému systému. Jejich suverenita je klimatickými změnami přitom značně zpochybněna. S moderním pojetím suverenity je totiž spojena představa statického teritoriálního prostředí, které se jako celek vztahuje k suverenitě a právnímu řádu jakožto nejvyššímu bodu v prostoru tak, že „všechny spojnice [...] jsou podřízeny jedinému bodu a všechny body jsou udělány tak, že rezonují s tímto centrem“ (Lee a Brown 1994: 784). Podobně jako je vše uvnitř berberského (kabylského) př́bytku absolutně podřízeno „paní domu“ a jeho obyvatelům bez jakékoliv vazby na to, jak se věci mají venku (Bourdieu 1970), jako by síly, mocnosti a vztahy, jejichž doménou je okolní krajina, nemohly vtrhnout dovnitř.

Domová suverenita, která je vlastní současným státům, tak výrazně kontrastuje s neurčitým a měnícím se prostředím krajiny, kde jsme vystaveni moci mimolidských sil. Oblasti masivně přeměňované požáry nebo zanikáním věčného ledu či ledovců však důrazně zpochybňují možnost, že krajinu lze pokládat za domácnost podléhající suverénní lidské moci. $\mathrm{V}$ tomto ohledu je proto určitě oprávněné pokládat moderní suverenitu spolu s Latourem za „špatně navržený produkt“, lze ji však rozmontovat a znovu složit a např́klad ji tak „očistit [...] od nevhodné fyziky, která do ní byla kdysi vsunuta“ (Latour 2016b: 310). Jednou z cest, jak toho dosíci, je výměna metafory domu v současném pojetí suverenity za přiléhavější představu krajiny. Vetknutí suverenity a práva do krajiny ve středověkém ústavněprávním zákoníku Maiestas Carolina může být v tomto ohledu pozoruhodnou inspirací např́klad pro uznání faktu, že moderní státy se skutečně nenacházejí v domech nebo jednoznačně ohraničených sociálních prostorech, nýbrž v relativně dosti otevřených krajinách.

Suverenita středověkého českého království je v Maiestas Carolina vetknuta do krajiny. Tato fyzicky i právně segmentovaná krajina je protějškem moderního geografického teritoria, jakož i monumentálním výrazivem jazyka středověké legitimity. Umožňuje totiž ustavit pravidelnou podobu suverénní autority multiplikací stejného vzorce $\mathrm{v}$ různých právních oblastech království. Královské lesy navíc umožňují zopakování téhož vzorce i mimo osídlený svět, v krajině archaické povahy s kvalitou divokosti a „věčnosti“. Bez královských lesů je suverenita království osamocena a omezena jen na lidský svět bez možnosti opírat se 
o trvalejší rysy širšího kosmologického řádu. Královské lesy totiž nejsou v Maiestas Carolina „anomálií““ v osídlené krajině, která by představovala narušení zavedených hierarchií. Naopak, jedná se o specifickou právní oblast, zvláštní konfiguraci suverenity a vzájemnosti středověkého právního světa, která je radikálně odlišná právě ve jménu zachování trvalosti království jeho zakotvením v širším řádu světa. Nezcizitelnost království, hlavní myšlenku Maiestas Carolina, je proto nutné chápat jako ústavní princip přesahující instrumentální a profánní zaměření. Jeho trvání je symbolicky manifestováno prostřednictvím monumentálních lesů přetrvávajících navzdory tomu, že jsou neustále vystaveny mocným př́rodním změnám.

\section{Literatura}

AGAMBEN, Giorgio. 2011. Homo Sacer: Suverenní moc a holý život. Praha: Oikoymenh.

BECHMANN, Roland. 1990. Trees and Man: The Forest in the Middle Ages. Saint Paul: Paragon House. BELLOMO, Manlio. 1995. The Common Legal Past of Europe: 1000-1800. Washington,D. C.: The Catholic University of America Press.

BELOW, Stefan von a Stefan BREIT. 1998. Wald - von der Gottesgabe zum Privateigentum: Gerichtliche Konflikte zwischen Landesherren und Untertanen um den Wald in der frühen Neuzeit. Stuttgart: Lucius \& Lucius.

BLAŽKOVÁ, Tereza. 2019. Zapomenuté stopy dřevař̃u na Šumavě. Praha: Veduta.

BLOK, Anders a Elgaard Jensen TORBEN. 2011. Bruno Latour: Hybrid Thoughts in a Hybrid World. London: Routledge.

BOHÁČ, Zdeněk. 1978. Dějiny osidleni Středního Povltaví v době předhusitské. Praha: Zemědělské muzeum, Ústav vědeckotechnických informací.

BOURDIEU, Pierre. 1970. „The Berber House or the World Reversed.“ Information (International Social Science Council) 9(2): 151-170.

BOURDIEU, Pierre. 1998. Teorie jednání. Praha: Karolinum.

BOURDIEU, Pierre. 2014. On the State: Lectures at the College de France, 1989-1992. Cambridge: Polity Press.

DERRIDA, Jacques. 1999. The Beast and the Sovereign I. Chicago, London: The University of Chicago Press.

DUVE, Thomas. 2017. „Was ist ,Multinormativität‘? - Einführende Bemerkungen.“ RechtsgeschichteLegal History $\operatorname{Rg}$ 25: 88-101.

DVOŘÁČKOVÁ-MALÁ, Dana a Jan ZELENKA. 2011. Curia ducis, curia regis: Panovnický dvưr za vlády Přmyslovců. Praha: Historický ústav.

ELIAS, Norbert. 2006. O procesu civilizace, Sociogenetické a psychogenetické studie I (Proměny chováni světských hornich vrstev na Západě). Praha: Argo.

ELIAS, Norbert. 2007. O procesu civilizace, Sociogenetické a psychogenetické studie II (Proměny společnosti, Nástin teorie civilizace). Praha: Argo.

FELDT, Laura. 2012a. „Wilderness in Mythology and Religion.“ Pp. 1-25 in Laura FELDT (ed.). Wilderness in Mythology and Religion: Approaching Religious Spatialities, Cosmologies, and Ideas of Wild Nature. Berlin, Boston: Walter de Gruyter.

FELDT, Laura. 2012b. „Wilderness and Hebrew Bible Religion: Fertility, Apostasy and Religious Transformation in Pentateuch." Pp. 55-94 in Laura FELDT (ed.). Wilderness in Mythology and Religion: 
Approaching Religious Spatialities, Cosmologies, and Ideas of Wild Nature. Berlin, Boston: Walter de Gruyter.

GIERKE, Otto. 1895. Deutsches Privatrecht: Systematisches Handbuch der deutschen Rechtswissenschaft. Lipsko: Duncker \& Humblot.

GRAZIANI, Monica a Philip BURNHAM. 2005. „Legal Pluralism in the Rain Forests of South-eastern Cameroon." Pp. 177-197 in Katherine HOMEWOOD (ed.). Rural Resources \& Local Livelihoods in Africa. New York: Palgrave Macmillan.

GRIMM, Jacob. 1828. Deutsche Rechtsalterthümer. Lipsko: T. Weicher.

GRIMM, Jacob. 1840-1863. Weisthümer. Gotinky: Dieterich.

HARRISON, Robert Pogue. 1992. Forests: The Shadow of Civilization. Chicago, London: University of Chicago Press.

HOLÝ, Vladimír. 2007. Královský hvozd na Šumavě před třicetiletou válkou. Domažlice: Nakladatelství Českého lesa.

HÜBNER, Rudolf. 1918. A History of Germanic Private Law. Boston: Little, Brown, and Company.

HUMPHREY, Caroline. 2007. „Sovereignty.“ Pp. 418-436 in David NUGENT a Joan VINCENT (eds.). A Companion to the Anthropology of Politics. London: Blackwell Publishing.

CHIFFOLEAU, Jacques. 1999. „Právo a práva.“ Pp. 525-539 in Jacques LE GOFF a Jean-Claude SCHMITT (eds.). Encyklopedie středověku. Praha: Vyšehrad.

JIREČEK ZE SAMOKOVA, Hermenegild. Codex iuris Bohemici: Jus terrae atque curiae regiae saeculi $X I V-m i$. Pragae: Typis Grégerianis.

JØRGENSEN, Dolly. 2010. „The Roots of the English Royal Forest.“ Anglo-Norman Studies XXXII: Proceedings of the Battle Conference 2009 32: 114-128.

KADLEC, Karel. 1897a. „Honební právo.“Pp. 538 in Jan OTTO (ed.). Ottův slovník naučný. Praha: J. Otto.

KADLEC, Karel. 1897b. „Regály.“Pp. 400 in Jan OTTO (ed.). Ottův slovník naučný XXI. Praha: J. Otto.

KANTOROWICZ, Ernst Hartwig. 1957. The King's Two Bodies: A Study in Mediaeval Political Theology. Princeton: Princeton University Press.

KLABOUCH, Jiří a Vladimír PROCHÁZKA. 1956. „Předpisy a obyčeje mezního práva v životě českého venkovského lidu v 17. a 18. století.“ Český lid 43(4): 158-162.

KLIMEK, Tomáš. 2014. Krajiny českého středověku. Praha: Dokořán.

KUBŮ, František. 1992. „Chebský lesní řád z roku 1379.“Pp. 209-221 in Miloslav POLÍVKA a Michal SVATOŠ (eds.). Historia docet: sbornik prací k poctě šedesátých narozenin prof. PhDr. Ivana Hlaváčka, CSc. Praha: Historický ústav Československé akademie věd.

LATOUR, Bruno. 1993. We Have Never Been Modern. Cambridge: Harvard University Press.

LATOUR, Bruno. 2005. Reassembling the Social: An Introduction to Actor-Network-Theory. Oxford: Oxford University Press.

LATOUR, Bruno. 2016a. Stopovat a skládat světy s Brunem Latourem: Výbor z textů 1998-2013. Praha: Tranzit.

LATOUR, Bruno. 2016b. „Onus Orbis Terrarum: About a Possible Shift in the Definition of Sovereignity.“ Millenium: Journal of International Studies 44(3): 305-320.

LEDVINKA, Tomáš. 2014. „From Border to Distance: The Formative Change towards Modern Legal Spatiality.“ Pp. 219-238 in Karolína PAUKNEROVÁ, Marco STELLA a Petr GIBAS (eds.). Non Humans in Social Science: Ontologies, Theories and Case Studies. Červený Kostelec: Pavel Mervart.

LEDVINKA, Tomášs. 2015. „Antropologie práva.“ Pp. 267-271 in Karel SCHELLE a Jaromír

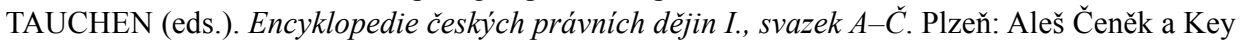
Publishing.

LEDVINKA, Tomáš. 2020a. „The Disenchantment of the Lore of Law: Jacob Grimm's Legal Anthropology before Anthropology.“ The Journal of Legal Pluralism and Unofficial Law 52(2): 203-226. 
LEDVINKA, Tomáš. 2020b. „Právo a antropologie. Distinkce, jež neskomírá““ Český lid 107(1): 3-21. LE GOFF, Jacques. 1992. „The Wilderness in the Medieval West.“ Pp. 47-59 in Jacques LE GOFF (ed.). The Medieval Imagination. Chicago: University of Chicago Press.

LEE, Nick a Steve BROWN. 1994. „Otherness and the Actor Network. The Undiscovered Continent.“ American Behavioral Scientist 37(6): 772-790.

LIEBRECHT, Johannes. 2016. Fritz Kern und das gute alte Recht: Geistesgeschichte als neuer Zugang für die Mediävistik. Frankfurt nad Mohanem: Vittorio Klostermann.

LOŽEK, Vojen. 2001. „Chráněná území ve světle své krajinné historie: Křivoklátsko - královský les ve středu Čech [Protected Areas in the Light of Their Landscape History: Křivokátsko - Royal Forest in the Centre of Bohemia]." Ochrana prírody/ The Journal of the State Nature Conservancy 56(4): $103-107$.

MANWOOD, John. 1717. Treatise of the Forest Laws: Shewing not only the Laws now in Force, but the Original of Forests. London: In the Savoy: Printed by E. Nutt (executrix of J. Nutt, assignee of E. Sayer) for B. Lintott (etc.).

MATTESON, Kieko. 2015. Forests in Revolutionary France: Conservation, Community, and Conflict 1669-1848. New York: Cambridge University Press.

NACHTMANOVÁ, Alena a Vladislav RAZÍM. 2010. „Křivoklát a lovecký hvozd v době přemyslovské.“ Pp. 12-35 in Vladislav RAZÍM (ed.). Přemyslovské Křivoklátsko: 900 let hradu Křivoklátu. Praha: Národní památkový ústav.

NODL, Martin a František ŠMAHEL. 2020. Pohané a křest'ané: Christianizace českých zemí ve středověku. Praha: Nakladatelství lidové noviny.

NOVÁK, Aleš. 2007. Dělník, nadčlověk, smrtelník. Tři podoby lidství člověka ve filosofické antropologii. Praha: Univerzita Karlova, Fakulta humanitních studií.

NOVOTNÁ, Eva. 2018. „Nejstarší mapy Českého království.“ Vesmir 97: 390.

NOŽIČKA, Josef. 1957. Přehled vývoje našich lesů. Praha: Státní zemědělské nakladatelství.

OELSCHLAEGER, Max. 1991. The Idea of Wilderness: From Prehistory to the Age of Ecology. New Heaven: Yale University Press.

PALACKÝ, František. 1844. „Majestas Carolina latině i česky.“ Pp. 65-67 in František PALACKÝ. Archiv český: čili, Staré písemné památky české i morawske III. Praha: Kronberger a Řiwnáč.

PAUKNEROVÁ, Karolína a Petr GIBAS. 2015. „Krajina jako téma, terén i problém současné společenské vědy: Antropologické čtení krajiny.“ Pp. 7-18 in Tereza BLAŽKOVÁ a Petra ČERVINKOVÁ (eds.). Krajina jako antropologická čitanka. Praha: Togga.

PAUKNEROVÁ, Karolína. 2019. Krajina mezi pamétí a zapomínáním. Praha: Karolinum.

POSPÍŠIL, Leopold. 1997. Etnologie práva: Teze o studiu práva z mezikulturní perspektivy. Praha: Set out. POSPÍŠIL, Leopold. 2004. Sociocultural Anthropology. Boston: Pearson Custom Publishing.

POTTAGE, Alain a Martha MUNDY. 2004. „Introduction: The Fabrication of Persons and Things.“ Pp. 1-39 in Alain POTTAGE a Martha MUNDY (eds.). Law, Anthropology, and the Constitution of the Social: Making Persons and Things. Cambridge: Cambridge University Press.

PURABI, Bose, Bas ARTS a Han van DIJK. 2012. ,,Forest Governmentality“: A Genealogy of Subjectmaking of Forest-dependent ,Scheduled Tribes“ in India.“ Land Use Policy 29(3): 664-673.

ROUX, Jean Paul. 2008. Král (Mýty a symboly). Praha: Argo.

SEINECKE, Ralf. 2017. „Rechtspluralismus in der Rechtsgeschichte.“ Rechtsgeschichte - Legal History $\operatorname{Rg} 25: 215-228$.

SHOEMAKER, Karl. 2018. „Germanic Law.“ Pp. 249-264 in Heikki PIHLAJAMÄKI, Markus D. DUBBER a Mark GODFREY (eds.). The Oxford Handbook of European Legal History. Oxford: Oxford University Press.

STOLLBERG-RILLINGER, Barbara. 2013. Des Kaisers alte Kleider: Verfassungsgeschichte und Symbolsprache des Alten Reiches. Mnichov: C. H. Beck. 
ŠUSTA, Josef. 1948. České dějiny II-4: Karel IV. - Za císařskou korunou 1346-1355. Praha: Jan Leichter. TAYLOR, Charles. 2002. „Modern Social Imaginaries. Popular Culture 14(1): 91-124.

TEIGE, Josef. 1904. „Rožemberská kniha.“ Pp. 35 in Jan OTTO (ed.). Ottův slovník naučný XXII. Praha: J. Otto.

THIMME, Hermann. 1909. „Forestis: Königsgut und Königsrecht nach den Forsturkunden vom 6. bis 12. Jahrhundert.“ Archiv für Urkundenforschung 2: 101-154.

TRIGGER, Bruce G. 1984. „Alternative Archaeologies: Nationalist, Colonialist, Imperialist.“ Man: New Series 19(3): 355-370.

ULlMANN, Walter. 1978. Scholarship and Politics in the Middle Ages: Collected Studies. Londýn: Variorum Reprints.

VANDERGEEST, Peter. 1996. „Mapping Nature: Territorialization of Forest Rights in Thailand.“ Society \& Natural Resources: An International Journal 9(2): 159-175.

WEBER, Max. 2009. Metodologie, sociologie, politika. Praha: Oikoymenh.

WEINER, Annette. 1992. Inalienable Possessions: The Paradox of Keeping-While-Giving. Berkeley: University of California Press.

WILliAMS, Georg H. 2016. Wilderness and Paradise in Christian Thought: The Biblical Experience of the Desert in the History of Christianity. Eugene: Wipf and Stock Publishers.

WOITSCH, Jiří. 2006. „Les živitel, člověk strašpytel: Strach z lesa ve středověku a raném novověku.“ Dějiny a současnost: Kulturně historická revue 11: 30-33.

WOITSCH, Jiří. 2007. „Člověk a les v dějinách: Ambiciózní teorie versus realita.“ Pp. 173-186 in Lucie STORCHOVÁ (ed.). Conditio humana - konstanta či historická proměnná? Koncepty historické antropologie a teoretická reflexe v současné historiografii. Praha: Univerzita Karlova, Fakulta humanitních studií.

WOITSCH, Jiří. 2010. „Dějiny lesa a lesnictví: Variabilita př́istupů a současné hlavní badatelské směry.“ Hospodářské dějiny 25(2): 199-226.

YOUNG, Charles R. 1978. „Conservation Policies in the Royal Forests of Medieval England.“ Albion: Journal of British Studies 10(2): 95-103.

\section{Autor}

Tomáš Ledvinka vystudoval antropologii a právo. Dlouhodobě se věnuje interdisciplinárnímu pomezí sociálních a právních věd, zejména antropologii práva, kterou v letech 2011-2017 rovněž přednášel na Fakultě humanitních studií Univerzity Karlovy. Byl hostujícím výzkumníkem na oddělení „Právo \& antropologie“ Max-Planckova institutu pro sociální antropologii v Halle a Mezinárodního institutu pro sociologii práva v Oñati. V současnosti se věnuje výzkumnému projektu „Kulturní podmíněnost moderního přístupu k právní jinakosti: etnologická perspektiva“ na Fakultě sociálních věd UK a přednáší o právu na Fakultě informatiky a managementu Univerzity Hradec Králové.

Kontakt: anthropology.law@gmail.com 